\title{
The Position of Humanities in the Curriculum of Architects and Urban Planners
}

\author{
KAREL SCHMEIDLER \\ Technical University of Brno \\ Czech Republic
}

\section{INTRODUCTION}

The place of sociology and related humanities in the curriculum of the Faculty of Architecture of the Technical University of Brno and other schools of architecture in the Czech Republic. Critical comments on the present situation. Sociology as a counterpart to the technically - oriented and limited approach of fine arts? Linking to other subjects, continuity, optimisation of tuition in the present and future system of professional education.

It is not necessary to speak too long about the need for the study of sociology within the framework of the professional education of architects, urban and territorial planners. Its introduction is based on the present problems of architectural and town planning practice. There are, for example, social problems connected with such a basic human need as housing. Social questions connected with the quality of the environment always preserve a quality of being up-to-date. Considerations concerning local groups and creation of neighbourhoods are closely connected with the problems of housing. Another group of questions is bound to the way of life of the modern urbanised city - dwellers at the end of 20 .. century, the design planning for which concerns almost all kinds of civil buildings.

The problem area of sociology has ever more contact with town - planning work and it has a considerable impact on the theory of town planning and a practical application that can be found in a whole range of the work, from the evaluation of socio - demographical indicators and human potential in a given territory to the revitalisation of degraded urban districts, the humanisation of urban settlements or studies dealing with the evaluation of the potential attendance rate for the facilities planned. A separate issue for the sociologist is rural sociology and today s problem sphere of village renewal.

The problems of sociology, psychology and anthropology have a considerable impact on the recent theories of architecture and town planning. Here, it is sufficient to remember the inspirational influence of the so-called theory of private spheres, territoriality, city image theory among others. The interest of sociology in architectural symbolism affects the development of architectural lines at the end of the 20 . century (postmodernism etc.).

Therefore, sociology is a subject which is taught at all significant schools of architecture. In Bohemia and Moravia, after a promising start in the period of the 1st republic when it was dealing also with architecture and the problems of town - planning, (studies of the urbanisation of villages around Prague as well as the then popular research on economical flats), sociology was prohibited with the arrival of the Nazis and with the subsequent persecution of our important sociologists for the first time. Sociology was also discriminated in the post-war years. For the second and third times it was removed from curricula in the Fifties, and again in the Seventies. It was also restricted in various ways in periods when it was permitted and it was forced to accept some controls that were forced on it. In our country a generation of architects graduated without having become acquainted with the sociology, its methods and applications. This may explain the absence of co-operation from both parties, mutual misunderstandings between architects and sociologists, the lack of confidence of urban planners and architects in the sociology, as well as in their notions of sociology as an especially theoretical subject, and the use of different terminology when analysing the same phenomena (e.g. sociology of housing and the typology of housing.)

In Western Europe and the USA, where there is a strong empirical tradition, the situation is quite different. Construction design is based on thorough socio-economic analysis and evaluation. This is then in compliance also with the range of humanities subjects in the curriculum of the schools of architecture. For example, at the "Eidgenossische technische Hochschule" in Zurich in Switzerland sociology is taught for four hours in two semesters. Lectures are supplemented with practical exercising classes and seminars where students deal with practical tasks. A similar situation can be found at the School of Architecture in Portsmouth in England, University in Kaiserslautern, Germany or at the Technical University in Lyngby near Copenhagen, Denmark. Of course, there are universities where the main stress is laid especially on the solution of the social problems connected with problems of planning problem as, for example at the univer- 
sity in Akron in the state of Ohio in the USA or some other French schools of architecture.

\section{THE POSITION OF SOCIOLOGY IN THE PRESENT CURRICULUM AT THE FACULTY OF ARCHITEC- TURE, TECHNICAL UNIVERSITY BRNO}

Sociology is one of the few art subjects in the programme of study at the Faculty of Architecture where two specialisation are studied - Architecture and Town - Planning and Physical and Regional Planning. Therefore it should create a counterpart to the purely technically - oriented or limited fine arts approach. It should be interconnected with other arts subjects, e.g. Philosophy, History of Arts, Environment Theory etc. Philosophy in the first year of study should provide the students with the background knowledge and terminology upon which Sociology could build. Horizontal and vertical linking of professional subjects - Physical Planning, Town Planning, Theory of Architecture, Typology of Constructions and studio work are also desirable as a matter of course. For this reason, as well as the consideration of the phenomenon psychologists call imprinting (i.e. optimum perception of the transferred knowledge in the initial phase of contact with the professional sphere and learning how to apply it in practice), the best place for them in the curriculum would be in lower years of study when the approach of a future architect to the solution of social problems could be developed, and he could be equipped with the necessary apparatus for their recognition and possible solution.

\section{OBJECTIVES OF THE SUBJECT AND ITS ROLE IN THE CURRICULUM}

Sociology makes the students acquainted with the theory of empirical knowledge of humanities subjects concerning architecture, town - planning and environment.

- It classifies the social and psychological needs of Man, and it outlines their satisfying by means of architectural and town - planning activities.

- It examines the theoretical and methodological background of architectural and artistic work. It explains the theory analysing the mutual relationship between society and environment created by architecture and town planning.

- It deals with the essential characteristics and structure of the population, family, etc. It outlines the essentials of related branches, e.g. demography.

- The students become acquainted with theoretical and empirical materials governing interaction between society and environment, both with regard to settlement complexes and housing estates and with regard to flats and houses.

\section{Topic areas for lectures in the 2nd year of study:}

1. Introduction to the Sociology course, its subject, object and theory. Introduction to Sociology as a separate sci- ence, basic definitions, methods, techniques and procedures. The most important sociological theories and their authors - with the stress laid on the latest developments and their relevance to architecture.

2. The relationship of architecture and sociology, the impact on the environment on the behaviour and consciousness of people, theories and hypotheses, the application of the knowledge of humanities in architecture, application in design planning.

3. Empirical research as a substantial part of knowledge in sociology. Methods, techniques, and procedures - an overview of procedures (observation, questioning, mapping, semantic differential, etc.) and ways of applying them in the environment.

4. The sociological theory of groups, sociometry, communication in groups, behaviour in groups. Social psychology, the leading and controlling of groups, the effectiveness of working in groups. Important for the architects for the reason that buildings form space for groups. Furthermore, architects, town planners and civil engineers are active in their professional activities as members of teams and they are mostly taking part in their management.

5. Territory and territorial behaviour, etology, territorial imperatives.

6. Family and housing from a sociological point of view. Social groups, professional groups and age groups and way of their housing. The structure, functions and changes in the families in the Czech Republic and in Europe. Social groups, professional groups and age groups and housing.

7. Types of residential houses and their influence on inhabitants and their way of life.

8. The housing requirements of specific groups of the population. Population in the post production age, preparation for occupation, disabled people and others.

9. Theories of neighbourhood and district, residential group and residential district, problems of district planning from a social point of view. The rise and development of the theories of district, positive and negative features from a sociological point of view.

11.Sociological expertise concerning new residential complexes. The humanisation of housing estates build in communist era.

12.The social aspects of the reconstruction of residential complexes, social pathology (criminality, disease, suicide rate, alcohol abuse, unemployment, etc.). The regeneration of central areas of the cities.

13.Cities and rural communities as social units. The social ecology of cities.

14.Urbanisation as a social and spatial process. Various definitions of urbanisation, specific features of urbanisation in Central Europe and in the Czech Republic.

15. Forecasting, futurology and scientific forecasting in sociology for the needs of architects and urban planners. Sociology in the fifth year of studies linked to the 2nd year course and other subjects taught at the Faculty of Archi- 
tecture of the Technical University in Brno. Lectures are aimed more at the sociology of the urban and rural life and at particular problems that are dealt with in individual studios.

\section{Topic areas for lectures in the II stage of study}

1. Physical Planning, Town - Planning and the Sociology of City life, the rise, development of and authors in the Urban sociology, the socio-economic determinants of the town - planning.

2. Settings (cities) as social spatial systems. The Chicago school and other socio - ecological theories. The Wirth theory - the importance and influence of the total amount, density and heterogenity of population.

3. The typology of settlements according to their functions. The summary of individual subsystems of the city system, questions of their mutual relationship, balance and their optimisation.

4. Population as a subsystem of the regional planning, the sociology and social psychology of the city dwellers, sociology of the village population.

5. Essential features of the demographic structure of settlements, more important demographic methods, analysis of demographic data in the work of the architect and urban planner.

6. The principal features of the demographic processes in individual types of settlements.

7. The forecasting of ways of life for the purposes of town - planning. Changes of the lifestyle in relation to the changes in the areas of culture and technology. Way of life and other socio - cultural aspects as determinants for the creation of settlements.

8. Investigative methods in the sociology of city life, critical evaluation.
9. The application of sociological knowledge in town planning, its background, methods, and essential procedures. Social aspects of territorial forecasting for settlements and large territorial complexes. Sociological methods for the determining of objectives for the development of settlements and their agglomerations, town planning and social planning.

10.Rural sociology - rise, development and important figures, rural sociology - sociology of suburban areas.

11.The determining of the socio cultural potential of cities, social indicators and their analysis.

12. Social psychology and its application in urban planning.

13.Social aspects which affect the design planning of new residential complexes.

14. Sociological aspects affecting the regeneration of city centres.

15. World urbanisation. Trends, range, positive and negative impacts and forecasting this, the specific features of urbanisation in individual continents and countries, and the differences between them.

In addition to the completion of the basic course of lectures, the student carries our supplementary work - in which an understanding of the theories of sociology and psychology is demonstrated, and the appropriate terminology is used. They deal either with a particular social phenomenon and its connection with architecture and town planning or socio-economic and demographic analysis of a particular community (or a part of it) or a particular region. The method described has been often used for the carrying our of research tasks at the Faculty of Architecture of the Technical University of Brno in the recent past. In spite of the experimental nature of this, very interesting results have been achieved by the students. 